\title{
IZIN POLIGAMI DALAM TINJAUAN FIKIH DAN HUKUM POSITIF DI INDONESIA
}

\author{
Ali Trigiyatno
}

\begin{abstract}
The government defined some norms on doing polygamy considering its negative effects. One of the requirements is a license for doing polygamy from the Religious Court. This letter of permission contains some benefits for the family especially protecting the right of the children and the wife.
\end{abstract}

Kata kunci: iz̨in poligami, bukum positif, fikih

\section{A. Pendahuluan}

Ada dua kata yang konon amat dibenci kaum perempuan, yakni dicerai dan dimadu. Diceraikan ditakuti karena bayangbayang menjadi janda yang dengan segala gosip dan predikat tak sedap lainnya, sedang dimadu menyiratkan sebgaian hak-haknya harus 'dibagi' dan 'direbut' dengan madunya yang tentu saja dirasakan 'menyakitkan' bagi sebagian besar wanita.

Bagi kaum laki-laki (para suami), berpoligami mungkin dirasakan sebagai suatu hak privilege yang menantang sekaligus mengasikkan. Sehingga pada umumnya kaum pria dapat memahami dan menyetujui poligami. Will Durant seorang sejarawan dari Inggris bahkan pernah menyatakan: "Man by nature is polygamous," sebuah pernyataan yang barang kali lebih banyak benarnya dibanding salahnya. 
Di Indonesia, poligami dibatasi dan diatur sedemikian rupa sehingga pelaksanaannya cukup sulit dan terbatas. Karena prosedurnya yang dirasa cukup berat dan 'jlimet', seperti keharusan izin terlebih dahulu ke PA, tidak jarang sebagian masyarakat memilih jalan pintas dengan melakukan nikah sirri yang disinyalir semakin marak dan bertambah. Model penikahan poligami 'liar' ini terkadang kurang disadari akibat-akibat buruk di kemudian hari terutama bagi isteri (kedua dst) dan anak-anaknya.

Tulisan ini mencoba menjelaskan kedudukan izin poligami ke Pengadilan Agama dalam sebuah perkawinan poligami dalam perspektif hukum Islam (fikih) dan hukum positif di Indonesia.

\section{B. Pengertian dan Sejarah Poligami}

Poligami merupakan praktik pernikahan kepada lebih dari satu suami atau isteri (sesuai dengan jenis kelamin orang bersangkutan) sekaligus pada suatu waktu. Terdapat tiga variasi atau bentuk poligami, pertama poligini yakni seorang pria memiliki beberapa isteri sekaligus, kedua poliandri yakni seorang wanita memiliki beberapa suami sekaligus, dan ketiga apa yang disebut dengan pernikahan kelompok (group marriage), yaitu pernikahan kombinasi antara poligini dan poliandri. ${ }^{1}$ Dari ketiga bentuk tersebut, poligami ${ }^{2}$ adalah bentuk perkawinan yang paling banyak ditemukan, walau ketiga-tiganya pernah dan masih ada dipraktikkan sampai masa sekarang ini. Walaupun diperbolehkan dan telah dipraktikkan dalam beberapa agama dan kebudayaan, poligami ditentang oleh sebagian kalangan yang lain, terutama kaum feminis menentang poligini, karena mereka menganggap poligini sebagai bentuk penindasan dan diskriminasi kepada kaum wanita. $^{3}$

\footnotetext{
${ }^{1}$ Pembahasan lebih lanjut baca Titik Triwulan Tutik \& Trianto, Poligami Perspektif Perikatan Nikah, cet. 1 (Jakarta: Pustaka Raya, 2007), hal. 44 dan seterusnya.

${ }^{2}$ Dalam tulisan ini kata poligini dimaknai sama dengan poligami. Dalam tulisan lebih lanjut, kata poligami lebih sering dipakai daripada kata poligini mengingat kata atau istilah poligami lebih familiar dalam penggunaan sehari-hari di masyarakat Indonesia.

${ }^{3}$ mnvw.wikipedia.org diakses 12 Nopember 2007.
} 
Secara etimologis poligami berasal dari bahasa Yunani Polus yang berarti banyak dan gamos yang berarti perkawinan. Secara harfiah poligami berarti suatu perkawinan banyak atau lebih dari satu pasang. Sedang yang dimaksud di sini poligami adalah sebuah bentuk perkawinan di mana dalam waktu yang bersamaan seorang pria atau suami memiliki lebih dari satu isteri. Sedang jika seorang isteri yang memiliki suami lebih dari satu lazim disebut dengan poliandri. ${ }^{4}$

Berbicara poligami sebenarnya usianya sudah sangat tua, setua peradaban umat manusia itu sendiri. Salah besar jika ada orang yang menuduh bahwa Islamlah yang mengintrodusir pertama kali pernikahan poligami ini. Karena nun jauh sebelum Islam diturunkan praktik poligami sudah dikenal dan cukup 'melembaga' di berbagai agama maupun budaya masyarakat di hampir seluruh dunia. ${ }^{5} \mathrm{Di}$ masyarakat Barat purbakala, poligami dianggap sebagai suatu kebiasaan karena lazim dilakukan para raja yang melambangkan ketuhanan, sehingga masyarakat menganggapnya sebagai sebuah perbuatan suci. ${ }^{6}$

Di kalangan umat Hindu, poligami juga cukup dikenal dalam arti banyak dipraktikkan sejak zaman dahulu. Demikian juga di kalangan Bangsa Israel, poligami sudah berjalan sejak zaman Nabi Musa AS yang terus dipraktikkan tanpa ada batasan isteri yang dapat diperisteri oleh seorang laki-laki. Kemudian Talmud di Jerusalem membatasinya sampai jumlah seorang suami mampu memelihara isteri-isterinya dengan baik. Meskipun para Rabbi menasihatkan supaya berpoligami tidak lebih dari empat orang isteri, namun kaum Ikarait tak mengakui pembatasan itu. ${ }^{7}$

${ }^{4}$ Untuk pengertian secara etimologis, lebih jauh dapat dibaca dalam Ensiklopedi Indonesia, (Jakarta: Ichtiar Baru Van Hoeve, 1984), V: 2736. Departemen Pendidikan dan Kebudayaan RI, Kamus Besar Babasa Indonesia (Jakarta: Balai Pustaka, 1988), hal. 693.

${ }^{5}$ Titik Triwulan Tutik \& Trianto, Poligami Perspektif Perikatan Nikah, cet. 1 Jakarta: Pustaka Raya, 2007), hal. 56.

6 Syed Ameer Ali, The Spirit of Islam (Delhi : Idarah-I Adabiyat-I Delli, 1978), hal. 222.

${ }^{7}$ Ibid,. hal. 223. 


\section{Ali Trigiyatno}

Menurut penuturan Nasarudin Umar, hampir semua agama dalam perkembangannya cenderung melarang atau sekurangkurangnya memberikan pembatasan ketat terhadap poligami. Agama Hindu, Budha, Yahudi, dan Nasrani semula memberikan pengakuan terhadap eksistensi poligami. Menurutnya, agama-agama tersebut terpengaruh dengan adanya asumsi budaya masyarakat yang menganggap bahwa makin banyak isteri seseorang maka dirasa makin tinggi status sosial yang diraih oleh laki- laki tersebut. Pusat-pusat peradaban dunia di masa lampau seperti Babilonia, Syiria, dan Mesir juga telah lama mengenal dan mempraktikkan poligami. Raja-raja mereka sudah terbiasa melakukan poligami, bahkan di Cina, lakilaki mempunyai isteri 3000 orang adalah sesuatu yang dianggap lumrah. Demikian pula agama besar sebelum Islam seperti Hindu, Budha, Yahudi dan Nasrani telah memberikan pengakuan terhadap eksistensi poligami.

Banyaknya isteri pada masa-masa klasik tersebut menjadi indikator dalam penentuan status sosial seseorang. Dalam Bibel tidak ditemukan ayat yang secara tegas menolak atau melarang poligami. Dalam Bibel diceritakan bahwa King Solomon (Nabi Sulaiman) mempunyai isteri sebanyak 700 orang.

Larangan poligami dalam agama Kristen muncul kemudian setelah renaisans, pada saat hukum-hukum gereja banyak mengadopsi hukum-hukum Romawi, sementara hukum Romawi banyak dipengaruhi oleh para pemikir humanis, terutama setelah Kaisar Yustianus menetapkan Corpus Luris Civils (biasa disebut Corpus Luris Yustianus) yang memuat hukum-hukum kekeluargaan (al-Aḅwäl alShakhsiyyah).

Bertolak dari Romawi, akhirnya hukum-hukum tersebut menyebar ke berbagai pelosok penjuru dunia dan dikembangkan oleh imperialisme Barat, seperti Napoleon yang terkenal dengan code civil yang dalam hal perkawinan menganut asas monogami. Napoleon Bonaparte yang menjadi simbol kekuatan Perancis menerapkan code civil ke berbagai negara jajahannya. Dalam 
sejarahnya, Perancis pernah menjajah Belanda yang kemudian Belanda menjajah Indonesia. Ketika menjajah Indonesia itulah Belanda menerapkan Burgerlijk Wetbook (BW), yang juga menganut asas monogami. ${ }^{8}$

\section{Tata Cara Poligami}

Dewasa ini beragam sikap yang ditunjukkan oleh negaranegara yang mayoritas penduduknya beragama Islam dalam menyikapi, mengatur dan memperlakukan poligami. Ada yang melarangnya secara ketat dan tegas dan bahkan mengkriminalkan bagi pelakunya seperti yang ditunjukkan oleh Turki dan Tunisia. ${ }^{9}$ Ada yang tidak melarangnya sama sekali, namun membatasinya dengan sejumlah syarat yang cukup berat, sikap seperti inilah yang kebanyakan diambil oleh negara-negara muslim termasuk Indonesia. Sedang sebagian yang lain mengambil sikap cukup bermudah-mudah dalam hal ini, poligami diperbolehkan sepanjang sesuai dengan aturan fikih pada umumnya. ${ }^{10}$

Di Indonesia, poligami diatur dalam UU Nomor 1 Tahun 1974 tentang Perkawinan khususnya pasal 4 dan 5. Dalam pelaksanaannya, ketentuan dimaksud dilengkapi dengan PP No. 9/1975 khususnya pasal 40 dan seterusnya. ${ }^{11}$ Khusus untuk PNS, pengaturan poligami ditambahkan secara lebih operasional dan ketat dengan dikeluarkannya PP Nomor 10 Tahun 1983 tentang Izin Perkawinan dan Perceraian bagi Pegawai Negeri Sipil yang disempurnakan dengan PP Nomor 45 Tahun 1945 tentang Perubahan atas Peraturan

${ }^{8}$ Lihat Nasarudin Umar, "Telaah Poligini," dalam www.antara.co.id. diakses 12 Nopember 2007.

9 Lihat Siti Musdah Mulia, "Menuju Hukum Perkawinan yang Adil : Memberdayakan Perempuan Indonesia,” dalam Sulistyowati Irianto (Ed.), Perempuan \& Hukum, cet. 1 (Jakarta: Yayasan Obor, 2006), hal. 136-137.

${ }^{10}$ Lebih jauh lihat Tahir Mahmood, Family Law Reform in The Muslim World (Bombay: NM Tripathi PVT Ltd., t.t.); juga bukunya yang berjudul Personal Lav in Islamic Countries (New Delhi: Acaademi of Law and Religion, 1987).

${ }^{11}$ Lihat Amiur Nuruddin dan Akmal Tarigan, Hukum Perdata Islam di Indonesia, cet. 2 Jakarta: Prenada Kencana, 2000), hal. 161 dan seterusnya. 
Pemerintah Nomor 10 Tahun 1983 Tentang Izin Perkawinan Perceraian bagi Pegawai Negeri Sipil. ${ }^{12}$

Pada dasarnya Undang-Undang perkawinan Nomor 1 tahun 1974 menganut asas monogami, yakni seorang pria dan atau seorang wanita dalam satu waktu hanya boleh memiliki satu isteri/suami. Namun dalam kondisi tertentu, celah pintu poligami terbuka bagi pria yang memiliki syarat-syarat tertentu untuk berpoligami. Seorang suami yang bermaksud melakukan poligami atau beristeri lebih dari seorang wajib mengajukan permohonan secara tertulis disertai alasanalasannya seperti tertuang dalam pasal 4 dan 5 UUP Nomor 1 tahun 1974 jo. Pasal 41 PP Nomor 9 tahun $1975 .{ }^{13}$

Adapun permohonan dimaksud ditujukan kepada pengadilan agama di daerah tempat tinggalnya dengan membawa kutipan Akta Nikah dan surat-surat izin yang dibutuhkan. Di samping harus mengajukan izin poligami sebagaimana diatur dalam pasal $40 \mathrm{PP}$ No. 9/1975, seorang suami yang ingin berpoligami harus memenuhi sejumlah syarat seperti diatur dalam pasal 4 ayat $2 \mathrm{UUP},{ }^{14}$ yang disebut dengan syarat alternatif, artinya syarat yang tidak harus dipenuhi semuanya, namun cukup jika salah satu ada maka dianggap sudah memenuhi syarat. Berbeda dengan ketentuan pasal 4 ini, maka keten-

${ }^{12}$ Poligami di Indonesia sebenarnya tidak banyak pelakunya. Sebelum ada UUP atau PP No. 10, jumlah perkawinan poligami tak lebiH dari $5 \%$. Setelah keluarnya UUP dan PP No. 10, jumlah tersebut semakin menurun. Namun jumlah poligami 'liar' boleh jadi lebih dari yang tercatat resmi di Pengadilan Agama. Nani Soewondi," Seminar on Law", hal. 34 sebagaimana dikutip oleh Azyumardi Azra, "The Indonesian Marriage Law of 1974: An Institutionalization of The Shari'a for Sosial Changes," dalam Arskal Salim \& Azyumardi Azra (Ed.), Shari'a and Politics in Modern Indonesia ( Singapore : Institute of Southeast Asian Studies, 2003), hal. 89.

${ }^{13}$ Baca lebih rinci dalam Sudarsono, Hukum Perkaninan Nasional, cet. 1, Jakarta: Rineka Cipta, 1991), hal. 27 dan seterusnya.

${ }^{14}$ Syarat-syarat tersebut adalah: (i) isteri tidak dapat menjalankan kewajibannya sebagai isteri; (ii) isteri mendapat cacat badan atau penyakit yang tidak dapat disembuhkan; dan (iii) Isteri tidak dapat melahirkan keturunan. Lihat Ahmad Rofiq, Hukum Islam di Indonesia, cet. 4 (Jakarta: Raja Grafindo Persada, 2000), hal. 171; Zainuddin Ali, Hukum Perdata Islam di Indonesia, cet. 2 (Jakarta: Sinar Grafika, 2006), hal. 47; Nuruddin \& Tarigan, Hukum Perdata Islam, hal. 162; Titik Triwulan Tutik \& Trianto, Poligami Perspektif Perikatan Nikah, cet. 1 (Jakarta: Pustaka Raya, 2007), hal. 137 dan seterusnya. 
tuan pasal 5 ayat 1 dan 2 yang bersifat kumulatif, artinya semuanya harus ada dan dipenuhi.

Terkait dengan prosedur poligami, ketentuan mengenai hal ini dapat dibaca pada PP No. 9/1975 pasal 40. Selanjutnya, pengadilan memeriksa permohonan izin tersebut sebagaimana diatur dalam pasal 41 PP No. 9/1975.

Dari berbagai aturan, syarat dan ketentuan mengenai poligami dapat disimpulkan, Indonesia termasuk negara muslim yang membolehkan poligami dengan melakukan pembatasan dan pengetatan terjadinya praktik tersebut. ${ }^{15}$

\section{Kedudukan Izin Poligami Menurut Fikih dan Hukum Positif}

Menurut hukum Islam klasik (fikih), tidak ada keharusan untuk melangsungkan poligami, tidak ada aturan-aturan seperti termuat dalam berbagai peraturan perundangan sekarang ini, termasuk di antaranya keharusan mengajukan izin permohonan poligami ke Pengadilan Agama. Pelibatan institusi Pengadilan Agama seperti yang ditentukan dalam UUP sama sekali tidak ada preseden historis dalam kitab-kitab fikih. ${ }^{16}$ Sehingga dalam praktik terkadang kurang dipatuhi oleh sebagian umat Islam karena dianggap tidak sejalan dengan kesadaran hukum mereka.

Hukum Islam 'hanya' mensyaratkan adanya keadilan dari suami yang oleh jumhur ulama dimaknai secara agak longgar yakni keadilan sebatas menyangkut persoalan fisik material seperti masalah sandang, pangan, papan dan giliran. Umumnya para

15 Adanya aturan yang ketat dan dirasakan mempersulit sebagian kalangan yang ingin berpoligami, beberapa waktu lalu ada gugatan untuk melakukan judicial review ke MK (Mahkamah Konstitusi) agar pasal-pasal yang mengatur atau lebih tepatnya membatasi poligami ditinjau ulang. Pengajunya adalah M. Insa seorang wiraswasta dari Jakarta. Permohonan Insa ini tidak dikabulkan oleh MK melalui putusan No. 12/ PUU-V/2007 yang dibacakan pada hari Rabu 3 Oktober 2007. Baca berita seutuhnya dalam mnv.mableamableonstitusi.go.id.

${ }^{16}$ Nurudin dan Tarigan, Hukum Perdata Islam, hal. 162. 
ulama fikih berpandangan bahwa poligami adalah boleh bahkan tak sedikit yang beranggapan sebagai sebuah sunnah Nabi SAW dan 'ibadah' dan menjadi hak 'istimewa' seorang suami tanpa persyaratan yang macam-macam dan menyulitkan itu. ${ }^{17}$

Namun demikian, berdasarkan prinsip maslahat mursalat, tidak ada halangan bagi penguasa (pemerintah) untuk menetapkan sebuah aturan atau pembatasan sepanjang hal itu didasari atas kepentingan umum yang lebih luas dan lebih menjamin kemaslahatan dan ketertiban masyarakat luas. Seorang penguasa dapat saja melarang, membatasi, mengatur sebuah ketentuan dalam agama yang hukumnya mubah dengan alasan dan pertimbangan yang cukup kuat untuk itu. Dengan demikian, batasan maupun aturan tambahan yang diberikan pemerintah untuk mengatur warga negaranya terkait dengan masalah poligami yang hukumnya antara sunah, mubah dan atau rukhsah, dapat dibenarkan dan diterima serta sudah semestinya ditaati. ${ }^{18}$

Kita tidak dapat menutup mata, bahwa poligami, terutama poligami liar, lebih sering dan banyak menimbulkan kemadharatan baik dalam skup keluarga (anak-anak, isteri-isteri, mertua, dan kerabat) maupun dalam level yang lebih luas. Sedang manfaat poligami lebih banyak dirasakan dan dinikmati oleh suami yang tentu saja jumlahnya lebih sedikit. Maka dari itu berdasarkan kaidah fikih dar' al-mafasid muqaddam 'alā jalb al-masălị̣ (menolak kerusakan didahulukan dari menarik manfaat), maka poligami dapat saja dibatasi dan diperketat untuk meminimalisir ekses-ekses negatif tersebut.

Sedang terkait dengan masalah keharusan memohon izin ke PA, berdasar pasal 9 UUP, izin poligami merupakan salah satu syarat untuk melangsungkan pernikahan lebih dari satu orang. Seseorang

${ }^{17}$ Pada umumnya, ulama tradisionalis dan fundamentalis memiliki pandangan yang cenderung longgar terhadap poligami. Sementara kalangan cendekiawan muslim dan kaum birokrat-terpelajar berpandangan agak memperketat poligami. Di sisi lain kalangan feminis muslim cenderung menentang untuk tidak mengatakan 'mengharamkan' poligami, sekurang-kurangnya haram lighayrib menurut pandangan Siti Musdah Mulia.

18 Pembahasan seputar maslahab mursalah lihat Mukhtar Yahya \& Fatchurrahman, DasarDasar Pembinaan Huleum Fikih Islami, cet. 3 (Bandung: Alma'arif, 1993), hal. 105 dan seterusnya. 
yang masih terikat perkawinan dengan orang lain dilarang melangsungkan pernikahan sebelum ada izin dari pengadilan. Petugas pencatat juga dilarang untuk mencatat sebuah perkawinan kedua dan seterusnya sebelum mendapat izin terlebih dahulu dari pengadilan. Seseorang yang tanpa mendapat izin dari pengadilan melangsungkan pernikahan kedua dan seterusnya dapat dibatalkan pernikahannya itu karena tidak mencukupi salah satu syarat. Ketentuan yang menegaskan bahwa jika perkawinan kedua dan seterusnya tidak mendapatkan izin dari pengadilan dapat dibatalkan terdapat dalam pasal 15 UUP.

\section{E. Menimbang Manfaat dan Madarat Poligami}

Pada dasarnya tidak ada di dunia ini suatu perbuatan yang semata-mata mendatangkan maslahat sebagaiman juga tidak ada perbuatan yang semata-mata mendatangkan madharat. Al-Qur'an secara jujur mengakui bahwa dalam khamr dan judi sekalipun terdapat beberapa manfaat walau harus digarisbawahi bahwa dosa dan madharatnya lebih besar daripada manfaatnya.

Terkait dengan praktik poligami di tengah-tengah masyarakat, secara jujur jika kita amati, tidak sedikit yang berhasil dalam arti tujuan perkawinan yang sakinab mawaddab wa rabmab dapat berhasil dicapai. Namun demikian, dengan mudah juga kita menjumpai pernikahan poligami yang justru memporak-porandakan ketenangan rumah tangga sebelumnya akibat satu dan lain hal, misalnya karena faktor ekonomi, psikologis, sifat yang tidak adil dan sebagainya.

Secara sederhana dan ringkas, beberapa manfaat atau katakanlah hikmah yang diharapkan dapat muncul dari adanya poligami dapat disebutkan sebagian di antaranya :

1. Bagi suami lebih memungkinkan untuk terhindar dari berbagai bentuk penyelewengan seperti perzinaan, pelacuran maupun perselingkuhan dengan mengambil langkah 'satria' menikah lagi dengan wanita lain. 


\section{Ali Trigiyatno}

2. Bagi sebagian isteri, dengan suami berpoligami beban untuk 'melayani' terutama kebutuhan biologis suami sedikit terkurangi.

3. Bagi isteri kedua dan seterusnya, lebih-lebih jika ia janda, dengan berpoligami, sebagian masalahnya ikut teringankan khususnya dalam hal mencari nafkah, membesarkan anak, dan mengurangi timbulnya fitnah di tengah-tengah masyarakat.

4. Bagi sebagian wanita, menjadi isteri kedua, ketiga atau bahkan keempat tidak menjadi masalah sepanjang ia mendapatkan laki-laki kaya lagi terhormat dan berpangkat, dalam kasus seperti ini, poligami bisa dikatakan dapat mengangkat derajat wanita.

5. Bagi anak atau anak-anak isteri kedua dan seterusnya yang berstus janda mendapatkan ayah tempat mengadu dan berlindung serta penjamin hidup atau nafkah.

Sementara dampak negatif dari poligami terutama bagi kalangan isteri (pertama) dan anak-anak dari isteri pertama dapat disebutkan sebagian di antaranya :

1. Dampak psikologis: perasaan inferior isteri dan menyalahkan diri karena merasa tindakan suaminya berpoligami adalah akibat dari ketidakmampuan dirinya memenuhi kebutuhan biologis suaminya dan juga ketidakmampuan 'membahagiakan' suami.

2. Dampak ekonomi rumah tangga: Ketergantungan secara ekonomi kepada suami. Walaupun ada beberapa suami memang dapat berlaku adil terhadap isteri-isterinya, tetapi dalam praktiknya lebih sering ditemukan bahwa suami lebih mementingkan isteri muda dan menelantarkan isteri dan anak-anaknya terdahulu. Akibatnya isteri yang tidak memiliki pekerjaan akan sangat kesulitan menutupi kebutuhan sehari-hari.

3. Kekerasan terhadap perempuan, baik kekerasan fisik, ekonomi, seksual maupun psikologis. Hal ini umum terjadi pada rumah tangga poligami, walaupun begitu kekerasan juga terjadi pada rumah tangga yang monogami. 
4. Dampak hukum: Seringnya terjadi nikah di bawah tangan (perkawinan yang tidak dicatatkan pada Kantor Catatan Sipil atau Kantor Urusan Agama), sehingga perkawinan dianggap tidak sah oleh negara, walaupun perkawinan tersebut sah menurut agama. Pihak perempuan akan dirugikan karena konsekwensinya suatu perkawinan dianggap tidak ada, seperti hak waris dan sebagainya.

5. Dampak kesehatan: Kebiasaan berganti-ganti pasangan menyebabkan suami/isteri menjadi rentan terhadap penyakit menular seksual (PMS), bahkan rentan terjangkit virus HIV/AIDS. ${ }^{19}$

Menurut al-Athar dalam bukunya Ta'addud al-Zawjāt sebagaimana dikutip oleh Khairudin Nasution dalam bukunya Riba dan Poligami: Sebuab Studi atas Pemikiran Mubammad Abduh, menjelaskan empat dampak negatif dari poligami yakni :

1. Menimbulkan kecemburuan antar isteri.

2. Menimbulkan kekhawatiran dan kegelisahan di kalangan isteri jika suami tak dapat berlaku adil.

3. Anak-anak yang lahir dari ibu yang berbeda sangat rawan terjadi permusuhan atau persaingan tidak sehat.

4. Kekacauan dalam bidang ekonomi. ${ }^{20}$

Apakah ada korelasi antara poligami dengan meningkatnya angka perceraian, yang berarti juga menimbulkan instabilitas rumah tangga seseorang?.

Dalam hal ini Nasarudin Umar, Dirjen BIMAS ISLAM Depag memaparkan sejumlah data menarik. Menurut catatan dari Pengadilan Agama di seluruh Indonesia, sebagaimana dituturkan oleh Nasaruddin Umar, pada tahun 2004 terjadi 813 kasus perceraian akibat poligami. Pada tahun 2005, angka itu naik menjadi 879 kasus dan pada tahun 2006 angka tersebut meningkat menjadi 983

19 id.wikipedia.org, diakses 12 Nopember 2007.

20 Khairudin Nasution, Riba dan Poligami : Sebuab Studi atas Pemikiran Mubammad Abduh, (Yogyakarta : Pustaka Pelajar, 1996), hal. 100. 
kasus. Menurutnya, berdasarkan data-data tersebut, poligami dituding menjadi penyebab meningkatnya angka perceraian. Dengan bahasa lain, poligami menjadi salah satu kontributor bubarnya sebuah pernikahan. Tidak hanya itu, poligami pun, lanjut dia, juga menyebabkan telantarnya perempuan dan anak-anak. Dibuatnya syarat izin isteri yang harus diperoleh seorang pria untuk berpoligami seperti yang diatur dalam UU Perkawinan, kata Nasarudin, dimaksudkan untuk mengurangi dampak buruk akibat poligami. ${ }^{21}$

\section{F. Konsekuensi Pernikahan Poligami tanpa Izin Pengadilan}

a. Status perkawinan

Menurut ketentuan pasal 9 UUP izin pengadilan merupakan sebuah keharusan bagi seorang suami yang hendak berpoligami. Persoalannya lantas bagaimana status hukum pernikahan kedua dan seterusnya yang tidak mendapatkan izin terlebih dahulu dari Pengadilan Agama?. UUP tampaknya belum atau tidak tegas menyatakan apa status hukumnya. Ia hanya mengatakan bahwa pernikahan kedua dan seterusnya yang tidak mendapat izin Pengadilan Agama dapat dicegah karena tidak memenuhi syarat-syarat untuk melangsungkan perkawinan. Sedangkan pernikahan poligami tanpa izin Pengadilan yang sudah terlanjur dilakukan, UU ini hanya mengatakan pernikahan itu dapat dibatalkan oleh Pengadilan. $^{22}$

Ketentuan UUP tersebut menurut penulis kurang jelas dan tegas, karena menggunakan kata-kata 'dapat' dicegah dan 'dapat' dibatalkan. Hal ini memberi kesan - dan kenyataanya memang demikian - UUP bersifat pasif, artinya dapat dicegah atau dibatalkan tentunya jika ada gugatan, laporan,

${ }^{21}$ wnv. republika.co.id, diakses 12 Nopember 2007.

${ }^{22}$ Lihat pasal 15 dan 24 UUP. Bandingkan Supardi Mursalin, Menolak Poligami Studi Tentang Undang-Undang Perkawinan dan Hukum Islam, cet. 1 (Yogyakarta: Pustaka Pelajar, 2007), hal. 34 . 
pengaduan atau keberatan dari pihak-pihak terkait sehubungan dengan adanya perkawinan kedua atau ketiga tersebut. Jika tidak ada keberatan, tentunya juga tidak begitu banyak persoalan dengan perkawinan kedua dan seterusnya tersebut.

b. Status anak dan isteri kedua dan seterusnya

Terkait dengan status perkawinan poligami tanpa izin pengadilan tersebut, membawa implikasi status pernikahan tersebut menjadi tidak jelas. Keberadaannya belum diakui UU sebagai perkawinan yang sah dan diakui oleh negara. Sehingga posisi isteri kedua dan seterusnya dan anak-anaknya menjadi kurang atau bahkan tidak terjamin kepastian hukumnya. Beruntung jika suami dan madunya bertanggung jawab dan baik-baik saja, namun jika terdapat masalah, tentunya kedudukan hukum isteri kedua dan anak-anaknya menjadi rentan dan lemah di mata hukum.

\section{G. Penutup}

Pada dasarnya manusia adalah makhluk berakal yang dengan akalnya dapat berpikir dalam menentukan sebuah sikap atau pilihan tindakan. Tindakan mana yang diambilnya harus disadari dan dilandasi dari segi boleh tidaknya, patut-tidak patut, ada manfaat atau tidaknya dan seribu satu pertimbangan lainnya. Dengan mengambil sebuah keputusan yang didasari dan dilandasi pertimbangan yang masak dan matang, diharapkan keputusan yang diambilnya tidak salah atau mengakibatkan kerugian di kemudian hari.

Berpoligami tanpa terlebih dahulu mendapat izin dari pengadilan jelas sebuah perbuatan melanggar hukum yang mestinya dihindari. Tindakan melanggar hukum sendiri bukanlah sebuah tindakan yang terpuji dari seorang warga negara dan tidak semestinya dilakukan. Ia tidak pantas dilakukan oleh warga negara yang baik dan juga seorang muslim yang agamis. 
Jika seorang ingin poligami hendaknya mengukur diri, sudahkah syarat-syarat yang ditetapkan oleh undang-undang sudah terpenuhi dan ada pada dirinya ataukah tidak, termasuk di dalamnya tentu persetujuan dari isteri pertamanya. Jika syarat-syarat itu tidak ada maka janganlah memaksakan diri buat melakukannya. Karena jika dipaksakan, bukan hanya izin poligami tak bakal didapat, lebih dari itu jika ia tetap nekad, maka segudang masalah dan mungkin juga setumpuk dosa bakal memayungi kehidupannya di masa datang.

Jika segala persyaratan sudah dipenuhi dan terpenuhi, maka tempuhlah dengan niat yang benar dan penuh kesadaran dan tanggungjawab dengan memenuhi hak-hak dan kewajiban hidup berumah tangga bagi orang yang berpoligami. Dalam hal ini bekal ilmu mengenai poligami berikut hak dan kewajiban yang melekat mutlak diperlukan. Namun jika tidak memenuhi syarat-syarat, maka memiliki isteri satu jelas lebih aman dan selamat dari segi kemungkinan berlaku tidak adil seperti penekanan ayat al-Qur'an surat an-Nisa' ayat 3 . 


\section{DAFTAR PUSTAKA}

Ali, Zainuddin. Hukum Perdata Islam di Indonesia. Jakarta: Sinar Grafika, 2006.

Fauzan, M. Pokok-Pokok Hukum Acara Perdata Peradilan Agama dan Mabkamah Syar'iyyah di Indonesia. Jakarta: Prenada Media, 2005.

Harahap, M. Yahya. Kedudukan Kewenangan dan Acara Peradilan Agama UU No. 7 Tabun 1989. Jakarta: Sinar Grafika, 2003.

Irianto, Sulistyowati (ed.). Perempuan \& Hukum. Jakarta: Yayasan Obor, 2006.

Al-Jahrani, Musfir., Poligami Dari Berbagai Persepsi, terj. Muh. Suten Ritonga. Jakarta: Gema Insani Press, 1996.

Machali, Rochayah (ed.). Wacana Poligami di Indonesia. Bandung : Mizan, 2005.

Mahmood, Tahir. Family Law Reform in The Muslim World. Bombay: NM Tripathi PVT LTD, t.t.

. Personal Law in Islamic Countries. New Delhi: Academy of Law and Religion, 1987.

Manan, Abdul. Penerapan Hukum Acara Perdata di Lingkungan Peradilan Agama. . Jakarta : Kencana Prenada, 2006.

Munti, Ratna Batara \& Hindun Anisah. Posisi Perempuan dalam Hukum Islam di Indonesia. Jakarta: LBH APIK, 2005.

Mulia, Siti Musdah. Islam menggugat Poligami. Jakarta: Gramedia, 2004. 
Ali Trigiyatno

Nuruddin, Amiur \& Azhari Akmal Tarigan. Hukum Perdata Islam di Indonesia. Jakarta: Prenada Kencana, 2004.

Rofiq, Ahmad. Hukum Islam di Indonesia. Jakarta: Raja Grafindo Persada, 2000.

Sosroatmodjo, Arso \& A. Wasit Aulawi. Hukum Perkawinan di Indonesia. Jakarta: Bulan Bintang, 1978.

Sudarsono. Hukum Perkawinan Nasional. Jakarta: Rineka Cipta, 1994.

Tutik, Titik Triwulan \& Trianto. Poligami Perspektif Perikatan Nikah. Jakarta: Pustaka Raya, 2007.

Zein, Satria Efendi M. Problematika Hukum Keluarga Islam Kontemporer Analisis Yurisprudensi dengan Pendekatan Ushuliyyah. Jakarta: Prenada Kencana, 2004.

Undang-Undang No. 1 Tahun 1974 tentang Perkawinan.

PP. No. 9 Tahun 1975.

PP. No. 10 Tahun 1983, PP. No. 45 Tahun 1990.

Inpres No. 1 Tahun 1991 Tentang Kompilasi Hukum Islam. www.gatra.com, diakses 3 April 2007.

bukumonline.com, diakses 5 Mei 2007

id.wikipedia.org/wiki/Poligami, diakses 12 Nopember 2007.

www.antara.co.id, diakses 12 Nopember 2007.

www.mabkamabkonstitusi.go.id. 